\title{
PERAN BAHASA INGGRIS SEBAGAI BAHASA KEDUA DALAM PEMEROLEHAN BAHASA INDONESIA SEBAGAI BAHASA KETIGA
}

\author{
Abdul Kholiq \\ Universitas Islam Lamongan, abdul.kholeq@gmail.com
}

\begin{abstract}
Cross language influence in third language (L3) acquisition is related to the first (L1) and second language (L2) acquisition. Cross-language influence in third language acquisition studies can be analyzed from the first and second language role in the third language acquisition. Each acquisition Indonesian language as L3 is always English as L2 so that the role of English in acquiring Indonesian as B3 be worth studying. It is a qualitative approach based research. This study focuses on (1) the role of English of articulation and (2) the role of English as the provider acquiring vocabulary in Indonesian as L3. Data used in this research is the conversation conducted by the researcher and research subject; and sentence production based on picture by the research subject. Data analysis result finds 1) the role of English as an addition to the mastery of the sound that is not owned B1 of pemeroleh Indonesian as L3 and English influence language sounds in pronunciation Indonesian, and 2) The role of English as a provider of vocabulary in language acquisition Indonesia as B3 is as a language bridge in language acquisition Indonesia if the Indonesian pemeroleh not master words in Indonesian. Keywords: Third language acquisition, english. role L2 in third language acquisition
\end{abstract}

\section{PENDAHULUAN}

Psikolinguistik sebagai cabang linguistik merupakan bidang kajian yang memiliki banyak subkajian. Salah satu subkajian tersebut adalah pemerolehan bahasa. Pada bidang pemerolehan bahasa dikenal pemerolehan bahasa pertama (B1) atau first language acquisition (FLA) dan pemerolehan bahasa kedua (B2) atau second language acquisition (SLA). Karena studi pemerolehan bahasa, baik FLA maupun SLA, selalu berkembang, hipotesis yang dirumuskan pada penelitian tertentu dapat diuji keabsahannya, dimungkinkan dimungkinkan akan menghasilkan hipotesis baru yang dapat disetarakan atau menggantikan hipotesis lama. 
Seseorang mengalami dua proses dalam pemerolehan bahasa, yaitu kompetensi dan performansi. Setiap orang memiliki kompetensi bahasa dalam dirinya, tetapi kompetensi itu akan terlihat pada performansi bahasa yang dihasilkannya. Jika dibandingkan pemerolehan B1 dengan B2, hanya sedikit pemeroleh B2 yang penguasaan B2-nya lebih baik dari B1-nya (Ghazali, 2013:1). Artinya, anak yang memperoleh B1-nya dengan baik akan memiliki kompetensi B1-nya lebih baik daripada B2-nya. SLA berlangsung pada orang yang sudah memperoleh B1. Hal itu dipengaruhi kondisi kognitif, kondisi lingkungan, dan proses psikologi setiap pemeroleh bahasa. Pada titik itulah studi pemerolehan bahasa menjadi unik dan menarik untuk terus diteliti.

Selain SLA, dalam beberapa dekade dikenal pula studi pemerolehan bahasa ketiga (B3) atau third language acquisition (TLA). Studi TLA berkaitan dengan bagaimana pengaruh B1 dan B2 pada TLA. Pengaruh bahasa-bahasa tersebut dalam kajian pemerolehan B3 dinamakan pengaruh lintas bahasa atau cross-linguistic influence. Studi lintas bahasa dalam TLA berpotensi lebih kompleks daripada studi pemerolehan lintas bahasa dalam SLA (Cenoz, 2001:1). TLA dialami oleh orang yang sedang memperoleh bahasa setelah menguasai B1 dan B2. Pemeroleh B3 tersebut dinamakan poliglot.

Dalam TLA, pemeroleh bahasa ketiga meminjam kata, kelompok kata, dan kalimat dari bahasa yang lebih lebih dekat tipologinya dengan bahasa target. Kellermen menyebutnya psikotipologi (dalam Cenoz, 2001:8). Pada TLA, sangat penting untuk dipertimbangkan kemampuan pemeroleh, tidak hanya pada bahasa target, tetapi juga dalam dua atau lebih bahasa lain yang telah dikuasai lebih dulu dikuasai pemeroleh B3. Hal tersebut menambah kompleksitas penelitian dengan mempertimbangkan kompetensi multilingual, bukan kompetensi monolingual.

Transfer bahasa dalam TLA yang memiliki andil besar dalam kajian pengaruh lintas bahasa adalah transfer leksikal. Hal tersebut disebabkan dari 178 | http://journal.unesa.ac.id/index.php/paramasastra 
Abdul Kholiq, Peran Bahasa Inggris... (hlm. 177-192)

transfer leksikal yang dilakukan pemeroleh B3 terlihat bagaimana pemerolehan B3 yang terjadi pada pemeroleh B3. Transfer leksikal menjadi fokus kajian yang paling banyak diteliti dalam TLA. De Angelis (2007:41) menyatakan bahwa dalam TLA dikenal transfer leksikal teradaptasi, teradaptasi dan transfer leksikal secara semantis.

Transfer leksikal takteradaptasi diasumsikan sebagai pemijaman leksikal dalam B1 atau B2 yang bentuknya utuh dalam B1 atau B2 yang tidak terpadukan dengan B3. Transfer leksikal teradaptasi diasumsikan sebagai pemijaman leksikal dalam B1 atau B2 yang bentuknya teradaptasi atau terpadukan dengan B3. Penjelasan tersebut dapat diperhatikan dari contoh berikut.

(1) Saya meng-cut kain itu.

(2) Saya cutting kain itu.

Pada kalimat (1) bentuk meng-cut terbentuk dari kata cut dalam bahasa Inggris dan imbuhan me- dalam bahasa Indonesia. Hal tersebut dapatk dikatakan sebagai transfer leksikal teradaptasi dari bahasa Inggris dan Indonesia. Pada kalimat (2) bentuk cutting adalah bentuk dari bahasa Inggris yang dianggap sebagai bentuk utuh dalam bahasa Inggris dalam transfer yang terjadi. Hal tersebut disebut sebagai transfer leksikal takteradaptasi.

Transfer leksikal secara semantis diasumsikan sebagai transfer leksikal yang penggunaannya tidak sesuai dengan maknanya dalam kalimat. Misalnya, pada kalimat saya ingin menjadikan dosen terdapat kata yang tidak sesuai dengan makna kata pada konteks kalimat tersebut, yaitu kata menjadikan. Kata menjadikan dapat bermakna membuat jadi. Dalam konteks kalimat tersebut makna kata menjadi lebih sesuai pada kalimat tersebut. 
Studi pengaruh lintas bahasa dalam TLA juga tidak terlepas dengan jarak bahasa dari B1 dan B1 terhadap B3 atau bahasa target (Cenoz, 2001: 8). Jarak bahasa diartikan sebagai kedekatan tipologi B1, B2, dan B3 pada kasus pemerolehan B3. Jarak bahasa berpengaruh pada pemeroleh B3 yang riwayat bahasanya saling berdekatan. Kellerman (dalam Cenoz, 2001:8) menyebut faktor jarak bahasa sebagai konsep psikotipologi bahasa.

Dalam kasus tersebut dapat diketahui bagaimana peran B1 dan B1 dalam TLA. Sebagai contoh, dalam memperoleh bahasa Indonesia, seseorang yang berB1 bahasa Inggris dan B2-nya bahasa Jepang diprediksikan lebih banyak mentransfer B1-nya, bahasa Inggris. Dengan kata lain bahasa sumber dalam konteks tersebut adalah bahasa Inggris.

Istilah pemerolehan B3 muncul dalam beberapa dekade terakhir untuk menjawab kasus pemerolehan bahasa pada seseorang yang bilingual, trilingual, atau multilingual. Istilah pemerolehan B3 jika dikaitkan dengan istilah pemerolehan B1 dan B2 diartikan sebagai bahasa yang diperoleh setelah B2. Hal itu berarti setelah B3 dikuasi akan muncul istilah B4 dan seterusnya jika seseorang belajar kembali bahasa selain bahasa-bahasa yang telah diperoleh. Istilah itu menjadi rancu karena seseorang mungkin mampu menguasai 40 bahasa. Apakah dalam menguasai bahasa keempat puluh tersebut dikatakan studi pemerolehan bahasa keempat puluh? Istilah pemerolehan B3 dibatasi dengan beberapa konsep dari beberapa ahli yang menekuni bidang pengaruh lintas bahasa.

Hammarberg (2001:22) berpandangan bahwa B2 dapat berupa lebih dari satu bahasa. Hammarberg menggunakan istilah B3 sebagai bahasa yang saat ini sedang diperoleh, sedangkan istilah B2 digunakan untuk bahasa lain yang diperoleh seseorang setelah B1 diperoleh. 
Abdul Kholiq, Peran Bahasa Inggris... (hlm. 177-192)

Seseorang yang memiliki B1 bahasa Spanyol saat belajar bahasa Inggris dapat dikatakan bahwa B2-nya adalah bahasa Inggris. Selanjutnya, jika seseorang yang ber-B1 bahasa Spanyol dan ber-B2 bahasa Inggris tersebut belajar bahasa Jerman, dapat dikatakan bahasa Jerman dari orang tersebut adalah B3. Jika seseorang dengan B1 bahasa Spanyol, B2 bahasa Inggris, dan B3 bahasa jerman belajar bahasa Indonesia, oleh Hammarberg bahasa Indonesia tidak dikatakan sebagai B4, tetapi dianggap sebagai B3.

Dari penjelas tersebut, istilah B2 diartikan sebagai bahasa yang telah dikuasai selain B1 sehingga B2 dapat terdiri lebih dari satu bahasa. Dari kasus yang dijelaskan pada paragraf sebelumnya, bahasa Inggris dan bahasa Jerman dikatakan sebagai B2. Hammarberg (2001:22) menuliskan bentuk B2 yang memiliki lebih dari satu bahasa tersebut dengan bentuk B2 $2_{n}$. Dari kalimat tersebut dapat dirumuskan $\mathrm{B} 21_{1}$ adalah bahasa inggris dan $\mathrm{B} 22_{2}$ adalah bahasa Jerman.

Batasan tersebut digunakan oleh linguis bidang pengaruh linntas bahasa pada pemerolehan B3 untuk memudahkan definisi istilah pada studi kasus pemerolehan B3. Istilah B3 itu sendiri dianggap baru oleh ahli pemerolehan bahasa karena munculnya bersaman dengan kemunculan studi pengaruh bahasa dalam pemerolehan bahasa.

Hammarberg (2001:20) menyatakan bahwa B1 dan B2 berperan pada artikulasi pemeroleh B3 dan sebagai penyedia kosakata dalam TLA. Peran B1 dan B2 pada artikulasi berhubungan dengan pelafalan pemeroleh B3 dalam pelafalan B3. Peran B1 dan B2 sebagai penyedia kosakata behubungan pada pengalihan kata B3 ke B1 atau B2 pemeroleh B3. Pengalihan tersebut diasumsikan sebagai leksikal altenatif saat pemeroleh B3 tidak menguasai kata pada B3. 
Pemeroleh bahasa Indonesia sebagai B3 akan sering kita temui pada warga negara asing yang dengan sengaja mempelajari bahasa Indonesia atau bertempat tinggal di Indonesia. Pemeroleh bahasa Indonesia tersebut akan menggunakan pengetahuan B1 atau B2-nya untuk dapat memahami bahasa Indonesia. Dalam kasus ini, umumnya pemeroleh bahasa Indonesia sebagai B3 memiliki riwayat bahasa Inggris sebagai B2 dan B1 sebagai bahasa asal negara mereka. Misalnya, orang Thailand dari daerah Thailand Selatan dengan bahasa ibunya Melayu Pattani yang saat ini mempelajari bahasa Indonesia memiliki riwayat bahasa setidaknya B1-nya adalah bahasa Melayu Pattani dan B2-nya adalah bahasa Thailand dan Inggris. Hal tersebut juga akan temui pada orang Cina (ber-B1 bahasa Mandarin) yang sedang memperoleh bahasa Indonesia akan memiliki B2 bahasa Inggris. Dari paparan tersebut, umumnya setiap pemeroleh bahasa Indonesia sebagai B3 akan ber-B2 bahasa Inggris.

Mengingat terbatasnya penelitian pengaruh lintas bahasa dalam pemerolehan bahasa Indonesia sebagai B3, studi pemerolehan B3 dikembangkan dan diteliti dengan memosisikan bahasa Indonesia sebagai bahasa target atau B3. Kasus yang terjadi tentang bahasa Indonesia sebagai B3 banyak ditemukan mahasiswa BIPA. Mahasiswa BIPA biasanya berasal dari bukan warga Negara Indonesia yang memiliki B1 yang beragam sehingga bahasa Inggris dijadikan pengantar untuk mempelajari bahasa Indonesia. Mereka mempelajari bahasa Indonesia tidak langsung dari B1 mereka. Akan tetapi, bahasa Inggris dijadikan sebagai jembatan untuk mempelajari bahasa Indonesia karena tipologi, bentuk kata dan struktur kalimat, bahasa Inggris dengan bahasa Indonesia berdekatan.

Penelitian pengaruh B3 dikembangkan dengan melihat peran bahasa Inggris sebagai B2 dalam pemerolehan bahasa Indonesia sebagai B3. Dengan memerhatikan uraian di atas, artikel ini terdiri atas dua fokus, yaitu (1) peran bahasa Inggris pada artikulasi dalam pemerolehan bahasa Indonesia sebagai B3 
Abdul Kholiq, Peran Bahasa Inggris... (hlm. 177-192)

dan (2) peran bahasa Inggris sebagai penyedia kosakata dalam pemerolehan bahasa Indonesia sebagai B3.

\section{Metode}

Pendekatan penelitian yang digunakan dalam penelitian ini adalah kualitatif. Pengumpulan data dilakukan dengan menggunakan teknik cakap semuka, rekam, catat, dan sadap (dalam Mahsun, 2007:128). Keempat teknik tersebut dilaksanakan dalam satu waktu pada setiap pengambilan data.

Subjek penelitian ini adalah tiga mahasiswa bahasa Indonesia untuk penutur asing (BIPA). Kriteria subjek penelitian yang diambil dalam penelitian ini adalah seseorang yang memperoleh lebih dari dua bahasa sehingga pemeroleh bahasa Indonesia dalam penelitian ini adalah pemeroleh B3. Penentuan subjek penelitian dilakukan dengan memperhitungkan masa pemerolehan bahasa Indonesia yang sama.

Mahasiswa BIPA yang menjadi subjek penelitian berasal dari BIPA Ubaya dan BIPA Unesa. Satu mahasiswa berasal dari BIPA Ubaya, sedangkan dua mahasiswa lainnya berasal dari BIPA Unesa. Ketiga mahasiswa tersebut mulai belajar bahasa Indonesia dalam waktu yang bersamaan, yaitu mulai belajar pada awal bulan September 2014. Agar lebih terinci, subjek penelitian penelitian ini dijabarkan sebagai berikut.

1. Rusfii Madiyoh (S-1)

Asal : Thailand

Keterangan :

- Umur 23 tahun

- B1: bahasa Melayu Pattani.

- B2 $2_{1}$ : Thailand (mulai dari 3 tahun sampai sekarang) 
- B22: Inggris (mulai dari 18 sampai 22 tahun)

- B3: Indonesia (mulai September 2014 sampai sekarang)

- Bahasa yang sering digunakan di keluarga: bahasa Melayu

2. Rakotoharimalala Patricia (S-2)

Asal : Madagaskar

Keterangan :

- Umur 19 tahun

- B1: Malagasi mulai dari 0 tahun sampai sekarang.

- B2 ${ }_{1}$ : Prancis (mulai dari 4 tahun sampai sekarang)

- $\mathrm{B} 2_{2}$ : Inggris (SMP sampai SMA)

- B3: Indonesia (mulai September 2014 sampai sekarang)

- Bahasa yang fasih atau sangat dikuasai: bahasa Prancis

3. Nandrian Rakotoarizaka (S-3)

Asal : Madagaskar

Keterangan :

- Umur 17 tahun

- B1: Malagasi mulai dari 0 tahun sampai sekarang.

- B2 $2_{1}$ : Prancis (mulai dari 4 tahun sampai sekarang)

- B22: Inggris (SMP sampai SMA)

- B3 : Indonesia (mulai September 2014 sampai sekarang)

- Bahasa yang fasih atau sangat dikuasai: bahasa Malagasi dan Prancis

Sumber data penelitian ini adalah percakapan antara subjek penelitian dengan peneliti dan kalimat yang diproduksi oleh subjek penelitian. Percakapan dilakukan peneliti dengan subjek penelitian dengan membicarakan topik yang tergolong ringan dan nonformal. Jika subjek penelitian takmampu menggunakan kata atau kalimat dalam bahasa Indonesia, subjek penelitian diperkenankan menggunakan B1 atau B2 subjek penelitian untuk menyampaikan sesuatu.

Sumber data yang kedua adalah produksi kalimat berdasarkan gambar. Produksi kalimat tersebut dilakukan dengan menggunakan media gambar yang berjumlah seratus gambar. Pemilihan seratus gambar yang disajikan tersebut 184 | http://journal.unesa.ac.id/index.php/paramasastra 
didasarkan pada kemungkinan bahwa subjek penelitian akan memproduksi minimal seratus kalimat karena ada seratus gambar yang disajikan. Gambar yang dipilih adalah gambar dengan kata kunci yang berhubungan dengan kurikulum BIPA.

Penganalisisan data yang digunakan dalam penelitian ini adalah hubung banding menyamakan dan membedakan (HBSB) yang dikemukakan oleh Mahsun (2007:117). Teknik HBSB berusaha menyamakan dan membedakan leksikal dan pelafalannya yang bukan termasuk dalam bahasa Indonesia. Hasil dari HBSB dilanjutkan pada analisis data untuk menjawab fokus transfer leksikal dan peran B1 dan B2 dalam pemerolehan B3.

\section{HASIL DAN PEMBAHASAN}

\section{Peran Bahasa Inggris pada Artikualasi dalam Pemerolehan Bahasa Indonesia sebagai B3}

Dari hasil penelitian, bahasa Inggris berperan sebagai penambah penguasaan artikulasi yang tidak terdapat pada B1 pemeroleh bahasa Indonesia. Hal itu terjadi pada S-2 dan S-3 yang ber-B1 bahasa Madagaskar.

Sesuai dengan sistem fonologi bahasa Madagaskar, dalam bahasa Madagaskar tidak terdapat bunyi $[\square],[\mathrm{c}],[\mathrm{x}],[\mathrm{q}]$, dan [w], sedangkan dalam bahasa Inggris sebagai B2 mereka dikenal bunyi $[\square],[\mathrm{c}],[\mathrm{x}],[\mathrm{q}]$, dan $[\mathrm{w}]$. Logikanya, bahasa Inggris sebagai B2 dari S-2 dan S-3 mampu memberikan penguasaan bunyi dalam pelafalan bahasa Indonesia sebagai B3 yang mengenal bunyi $[\square],[\mathrm{c}]],[\mathrm{x}],[\mathrm{q}]$, dan [w]. Hal tersebut terlihat pada data yang diucapkan S-2 sebagai berikut.

(a) Saya course. $\rightarrow$ [saya] [k®urs]. (S-2)

(b) Kesulitan saya bahasa Indonesia di kata-kata sedikit and vocabulary. $\rightarrow$ [K ॐ sulitan] [saya] [bahasa] [Indonesia] [di] [vokabulari]. (S-2) 
Pada kalimat (1) terlihat bahwa dalam bahasa Inggris sebagai B2 2 -nya dari S-2 terdapat kata course yang diucapkan [k-urs] oleh S-2. Dari kata tersebut S-2 mengenal huruf /c/ yang dilafalkan [k]. Pada kalimat (2) S-2 mengucapkan kata kesulitan kata vocabulary dengan lafal [k ${ }^{\circ}$ sulitan] dan [vokabulari] yang menunjukkan bahwa S-2 juga sudah mengenal bunyi [ $\square]$ dan [c]. Hal tersebut juga terlihat pada data berikut.

(c) Box letter itu ada banyak kertas $\rightarrow$ [boks] [lett $\square \mathrm{r}$ ] [itu] [ada] [ba $\square \mathrm{a}$ ?] [kertas]. $(\mathrm{S}-2)$

(d) Orang muslim berdoa di mosque $\rightarrow$ [ora $\square$ ] [muslim] [berdoa] [di] [moske]. (S-2)

(e) Ibu mengajar anaknya untuk walking $\rightarrow$ [ibu] [m $\square$ ajar] [ana? $\square$ a] [untuk] $[\mathrm{w} \oplus 1 \mathrm{ki} \square]$. (S-2)

Pada kalimat (c) terlihat bahwa S-2 mengenal bunyi [x] pada kata box letter yang diucapkan [boks] [lett $\square \mathrm{r}$ ]. Pada kalimat (d) terlihat bahwa S-2 mengenal bunyi [q] pada kata mosque yang diucapkan [moske]. Pada kalimat (e) terlihat bahwa S-2 mengenal bunyi [w] pada kata walking yang diucapkan [w๑lki $\square]$. Dari kata yang ditransfer ke bahasa Inggris S-2 tersebut, terlihat bahwa S-2 secara tidak langsung juga bersama dengan mengenal bunyi [ $\square],[\mathrm{c}],[\mathrm{x}],[\mathrm{q}]$, dan [w] dari kata dalam bahasa Inggris mereka sebagai B2.

Dari paparan data di atas dapat dikatakan bahwa bahasa Inggris memiliki peran sebagai penambah penguasaan bunyi dalam pelafalan pemeroleh bahasa Indonesia sebagai B3. Setiap bahasa memiliki karakteristik yang tidak dimiliki oleh bahasa yang lain. Karakteristik tersebut dapat terdapat pada sistem fonologis, morfologis, dan sintaktis. Jika seseorang menguasai lebih dari dua bahasa, dapat dimungkinkan seseorang tersebut akan menguasai perbandingan bahasa yang dikuasai dan mampu mengorganisasi bahasa yang dimiliki untuk mempermudah dalam menguasai bahasa yang akan diperoleh. Hal tersebut terlihat pada S-2 dan S-3.

186 | http://journal.unesa.ac.id/index.php/paramasastra 
Selain sebagai penambah penguasaan artikulasi, bahasa Inggris juga memengaruhi pelafalan S-2 dan S-3. Dari contoh kalimat (c), S-2 melafalkan kata kertas dengan lafal [kertas] bukan [k $\square$ rtas]. Hal tersebut terlihat bahwa fonologi bahasa Inggris yang jarang menggunakan bunyi [ $\square$ ] dalam pelafaan katanya. Pada kalimat (d) kata berdoa yang dilafalkan dengan [berdoa] bukan [b $\square$ rdoa]. Data lainnya dapat dilihat pada kalimat berikut.

(f) Saya mencoba makan honey. $\rightarrow$ [saya] [mencoba] [makan] [hanie]. (S-3)

(g) Pacar Stevani memberi rose $(\mathrm{P}) \rightarrow$ [pacar] [stevani] [memberi] [ros]. (S-2)

(i) Ibu membeli plat berwarna putih (P) $\rightarrow$ [ibu] [m $\square \mathrm{mb} \square$ li] [plat] [berwarna] [putih]. (S-2)

Pada kalimat (f) dan (g) S-2 dan S-3 melafalkan kata mencoba dan memberi dengan lafal [mencoba] dan [memberi], bukan [m\ncoba] dan $[\mathrm{m} \unrhd$ mberi]. Pada saat tertentu S-2 dan S-3 kembali melafalkan kata dengan karakteristik B1-nya yang tidak mengenal bunyi [ $\square \square \square \square$ Akan tetapi, pada kalimat (i) S-2 mengucapkan kata membeli dengan lafal $[\mathrm{m} \square \mathrm{mb} \square$ li]. Dari data tersebut terlihat bahwa pemeroleh bahasa Indonesia sebagai B3 dengan B2-nya bahasa Inggris sulit untuk membedakan distribusi bunyi [ $\square \square \square$ dalam pelafalan bahasa Indonesia.

\section{Peran Bahasa Inggris sebagai Penyedia Kosakat Pemerolehan Bahasa Indonesia sebagai B3}

Peran B2 sebagai penyedia kosakata disajikan dalam tiga bagian. Pertama, peran bahasa Inggris (B2 2$)$ dari S-1, S-2, dan S-3 sebagai penyedia kosakata dalam memperoleh bahasa Indonesia sebagai B3. Kedua, peran bahasa Prancis $\left(B 2_{1}\right)$ dari $\mathrm{S}-2$, dan S-3 sebagai penyedia kosakata dalam memperoleh bahasa Indonesia sebagai B3. Ketiga, peran bahasa Thailand (B21) dari S-1 sebagai penyedia kosakata dalam memperoleh bahasa Indonesia sebagai B3. 
Pemaparan hasil penelitian tentang peran B2 sebagai penyedia kosakata dalam pemerolehan B3 disajikan sebagai berikut.

a. Peran Bahasa Inggris (B2 2$)$ sebagai Penyedia Kosakata dalam Pemerolehan Bahasa Indonesia sebagai B3

Bahasa Inggris sebagai $\mathrm{B} 22_{2}$ dari S-1, S-2, dan S-3 berfungsi sebagai penyedia kosakata saat S-1, S-2, dan S-3 tidak menguasai suatu kata dalam bahasa Indonesia. Kata yang tidak mereka kuasai ditransfer ke bahasa Inggris yang menunjukkan dalam pikiran mereka bahasa Inggris dijadikan sebagai penyedia kosakata untuk memahami kata tertentu dalam bahasa Indonesia. Hal tersebut dapat dipahami dari data berikut.

(j) Kalau dosen mau marah pada saya itu saya harus care. (S-1)

(k) Saya sulit remember. $(\mathrm{S}-2)$

(1) After Maroko mengajar Inggris di Madagaskar. (S-2)

(m) Nanti announcement lewat online. (S-1)

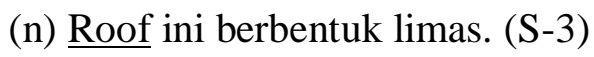

(o) Dia merapikan tie. $(\mathrm{S}-3)$

Pada kalimat (j) S-1 menggunakan kataa care untuk menyatakan kata peduli. Kata care dalam bahasa Inggris berada dalam otak S-1 untuk menyatakan kata peduli. Penyediaan kata care untuk kata peduli dalam pikiran S-1 menunjukkan bahwa bahasa Inggris juga sebagai penyedia kosakata dalam bahasa pemerolehan bahasa Indonesia, selain bahasa melayu. Hal yang juga terjadi pada kalimat (k) dan (1). S-2 mengucapkan kata remember dan after untuk menggantikan kata ingat dan setelah. S-1 menggunakan kata announcement pada 
Abdul Kholiq, Peran Bahasa Inggris... (hlm. 177-192)

kalimat (m) untuk menggantikan kata pengumuman. Pemilihan kata announcement tersebut dilakukan S-1 karena dia tidak menguasai kata pengumuman dalam bahasa Indonesia dan Melayu sehingga bahasa Inggris S-1 berfungsi sebagai penyedia kata untuk menggantikan kata pengumuman.

Kata roof dan tie digunakan oleh S-3 untuk menyatakan kata atap dan dasi pada kalimat (n) dan (o). Hal tersebut dilakukan karena S-3 tidak mengerti kata atap dan dasi dalam bahasa Indonesia sehingga digunakan bahasa Inggris untuk menggantikan. Data lain dapat dilihat pada data kalimat berikut.

(p) Letter itu kiriman dari teman saya. (S-1)

(q) Orang-orang sedang meeting (S-1)

(r) Di kantor adalah tempat untuk meeting (S-2)

(s) Orang itu belajar driving (S-2)

(t) Saya mencoba makan honey. (S-3)

(u) Mereka jumping di pantai (S-3)

Pada kalimat (p) kata letter digunakan S-1 untuk menggantikan kata surat karena S-1 terlintas kehilangan kata surat dalam bahasa Indonesia dan Melayu sehingga kata dalam bahasa Inggris, letter, digunakan S-1 untuk mengungkapkan maksudnya. Kata meeting digunakan S-1 dan S-2 pada kalimat (q) dan (r) untuk menggantikan kata rapat karena mereka tidak mengerti kata rapat dalam bahasa Indonesia. Kata driving, honey, dan jumping digunakan S-2 dan S-3 untuk menggantikan kata mengemudi, madu, dan melompat karena mereka tidak mengetahui kata-kata tersebut dalam bahasa Indonesia. 
Data yang disajikan di atas adalah data transfer leksikal takteradaptasi yang dilakukan S-1, S-2, dan S-3. Data transfer teradaptasi juga menggunakan bahasa Inggris sebagai paduan kata dalam leksikal teradaptasinya. Hal tersebut dapat diperhatikan pada data berikut.

(v) Banyak. Tentang menulis, mendengar, semua skill-nya kurang lagi karena kuliahdalam kelas saja. (S-1)

(w) Vocabulary-nya kurang. (S-3)

(x) Saya meng-cutting kertas itu . (S-2)

(y) Anaknya di-massage oleh ibunya . (S-3)

Pada kalimat (v) S-1 menggunakan kata skill-nya yang menunjukkan bahwa kata tersebut merupakan kata yang ditransfer secara teradaptasi. Kata skillnya terbentuk dari kaata skill dalam bahasa Inggris dan bentuk -nya dalam bahasa Indonesia. Kata skill dalam bahasa Inggris S-1 digunakan untuk menyatakan kata kemampuan. Artinya, bahasa Inggris digunakan S-1 sebagai penyedia kata saat tidak menguasai kata dalam bahasa Indonesia meskipun dipadukan dengan bentuk - nya dalam bahasa Indonesia. Hal yang sama juga dilakukan S-3 pada kata vocabulary-nya pada kalimat (w) yang terdiri atas kata vocabulary dalam bahasa Inggris dan bentuk - nya dalam bahasa Indonesia.

Bentuk transfer leksikal teradaptasi yang berbentuk meng-cutting dilakukan S-2 pada kalimat (x) dengan memadukan kata cutting dalam bahasa Inggris dan bentuk afiks me-dalam bahasa Indonesia. Kata cutting dalam bahasa Inggris digunakan S-2 untuk menggantikan kata memotong meskipun dipadukan dengan bentuk dalam bahasa Indonesia, afiks me-. Hal yang sama juga dilakukan S-3 yang menggunakan bentuk di-massage untuk menyatakan bentuk memijat dalam bahasa Indonesia pada kalimat (y). Massage adalah kata disediakan 
Abdul Kholiq, Peran Bahasa Inggris... (hlm. 177-192)

dipikiran S-3 dalam bahsa Inggris yang digunakan S-3 untuk memadankan kata memijat dalam bahasa Indonesia. Hal tersebut menunjukkan bahwa bahasa Inggris digunakan sebagai penyedia kata saat kata dalam bahasa Indonesia belum dapat dikuasai.

\section{SIMPULAN}

Dari uraian di atas, dapat disimpulkan sebagai berikut.

1. Peran bahasa Inggris pada artikulasi dalam pemerolehan bahasa Indonesia sebagai B3 adalah sebagai penambah penguasaan bunyi yang tidak dimiliki B1 dari pemeroleh bahasa Indonesia sebagai B3 dan bahasa Inggris memengaruhi bunyi bahasa dalam pelafalan bahasa Indonesia.

2. Peran bahasa Inggris sebagai penyedia kosakata dalam pemerolehan bahasa Indonesia sebagai B3 adalah sebagai bahasa jembatan dalam pemerolehan bahasa Indonesia jika pemeroleh bahasa Indonesia tidak menguasai kata dalam bahasa Indonesia. Hal tersebut terlihat pada transfer leksikal, baik teradaptasi, takteradaptasi, maupun semantis, yang ditransfer ke dalam bahasa Inggris.

\section{DAFTAR PUSTAKA}

Cenoz, Jasone, et. al (eds). 2001. Cross-Linguistic Influence in Third Language Acquisition. Multilingual Matters: Clevedon.

De Angelis, Gessica. 2007. Third or Additional Language Acquisition. Multilingual Matters: Clevedon.

Ghazali, A. Syukur. 2013. Pemerolehan dan Pembelajaran B2. Malang: Bayumedia Publishing. 
Hammarberg, B. 2001. "Roles of L1 and L2 in L3 production and acquisition". In J. Cenoz, B. Hufeisen, \& U. Jessner (Eds.), Cross-linguistic influence in third language acquisition:Psycholinguistic perspectives (pp. 21-41). Clevedon, UK: Multilingual Matters.

Mahsun. 2007. Metode Penelitian Bahasa Tahapan Strategi, Metode, dan Tekniknya (Edisi Revisi). Jakarta: PT Raja Grafindo Jaya. 